IRSTI 10.85 .01

\author{
Tapalova R.B. ${ }^{1}$, Temirbolat N.S. ${ }^{2}$, Daubasova S. ${ }^{3}$, Arvind T.T. ${ }^{4}$ \\ ${ }^{1}$ candidate of Legal Sciences, associate Professor, e-mail: tapalova_r@mail.ru \\ ${ }^{2}$ candidate of Legal Sciences, acting as Docent, e-mail: nuraishamail@gmail.com \\ ${ }^{3}$ Senior Lecturer, e-mail: daubassova2017@gmail.com \\ Al-Farabi Kazakh National University, Kazakhstan, Almaty \\ ${ }^{4}$ Professor of Law at York Law School United Kingdom, Heslington, York, e-mail: t.t.arvind@york.ac.uk
}

\title{
PATHOGENIC MICROORGANISM AS AN ELEMENT OF FORENSIC CHARACTERISTICS OF BIOTERRORISM
}

This article is devoted to forensic research of the damage circumstances by pathogenic microorganism in the environment after a terrorist attack. The topic is relevant in that it has not yet been studied in forensic such notions as "especially dangerous infections", "biological agents", "bacteriological weapons", "biological weapons", "pathogenicity", "contagious properties", etc. were not considered in the literature. In forensic science, the properties of biological agents of biological weapons developed to date, the mechanism and nature of trace formation in the material situation where a terrorist act can be committed using these means are not systematized. The issues of technical and forensic support for conducting investigative actions were not considered, for example, when inspecting the scene of an incident, if an act of terrorism was committed, there are no recommendations on the tactical features of investigating this category of crimes, and the specialists are not known in what procedural form. Specialists should be established to prove the guilt of the terrorist (s), and other issues are not developed as well. of terrorism.

The purpose of research, based on the properties of pathogenic microorganisms of natural origin and biological agents for creating biological weapons, their existing classification by degree of pathogenicity, method of penetration, etc., to identify the main properties of these microorganisms in the forensic aspect, systematize them to determine the tactics of the investigation at the initial stage of the investigation.

Scientific works of microbiologists, virologists, biologists, epidemiologists and military epidemiologists devoted to the biological agents and the weapon, the methods of indication of bacteriological materials, also the works of criminologists devoted to the theory and practice of investigating special types of crime served as a basis to this article.

Key words: act of terrorism, pathogenic microorganism, biological agents, especially dangerous infections, biological weapon, virus, pathogenic bacterial, rickettsia, toxins, tactics, investigative actions.

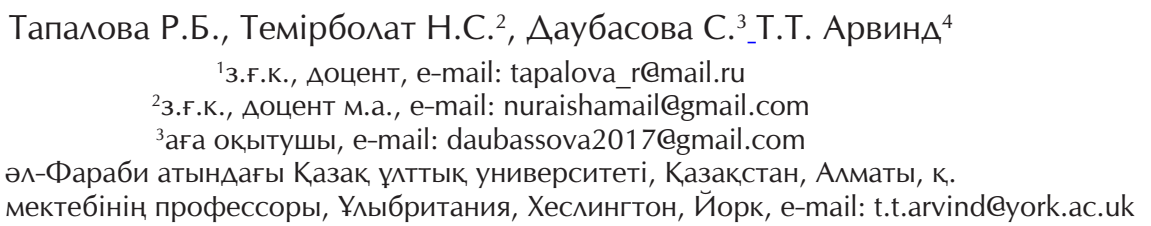

Патогенді микроорганизмдер биотерроризмнің криминалистикамық сипаттамасының эмементі ретінде

Мақала терроризм актісін жасау кезінде патогенді микроорганизмдермен материалдық ортаның зақымдану жағдайларын криминалистикалық талдауға арналған. Зерттеу тақырыбының өзектілігі қазіргі уақытқа дейін криминалистикалық әдебиетте зерттелмегендігімен және «аса қауіпті инфекциялар», «биологиялық агенттер», «бактериологиялық қару», «биологиялық қару», «патогенділік», «контагиозды қасиеттер» және т.б. ұғымдар қарастырылмағандығымен түсіндіріледі. Криминалистикада қазіргі уақытта әзірленген биологиялық қарудың биологиялық агенттерінің қасиеттері, көрсетілген құра^дарды қолдана отырып, террористік акт жасалуы 
Tapalova R.B. et al.

мүмкін материалдық жағдайда іздің пайда болу механизмі мен сипаты жүйеленбеген. Іздестіру тергеу әрекеттерін жүргізуді техникалық-криминалистикалық қамтамасыз ету мәселелері қаралмаған, мысалы, оқиға болған жерді тексеру кезінде, егер терроризм актісі жасалған болса, осы санаттағы қылмыстарды тергеудің тактикалық ерекшеліктері бойынша ұсыныстар жоқ, мамандар қандай процессуалдық нысанда іске тартылуы тиіс, террористің (-тердің) кінәлілігін дәлелдеу үшін қандай мән-жайлар және қандай мамандардың көмегімен анықталуы тиіс, сондайақ, терроризм қылмыстарын тергеу әдістемесін құрайтын өзге де сұрақтар зерттелген емес.

Зерттеудің мақсаты, биологиялық қару жасау үшін қолданылатын табиғи патогенді микроорганизмдердің және биологиялық агенттердің қасиеттеріне сүйене отырып, олардың патогенАік дәрежесі бойынша, ену тәсілі және т.б. бойынша қазіргі жіктемесіне сүйене отырып, бұл микроорганизмдердің негізгі қасиеттерін криминалистикалық аспектіде бөліп көрсету, тергеудің бастапқы кезеңінде тергеу жүргізу тактикасын анықтау үшін оларды жүйелендіру.

Биологиялық агенттерге, биологиялық қаруға, бактериалогиялық материалды индикациялау әдістеріне арналған микробиологтардың, вирусологтардың, биологтардың, эпидеомиологтардың, әскери эпилеомиологтардың ғылыми еңбектері, сондай-ақ қылмыстың жекелеген түрлерін тергеу теориясы мен практикасына арналған криминалистердің еңбектері әдіснамалық негіз болды.

Түйін сөздер: терроризм актісі, патогенді микроорганизмдер, биологиялық, агенттер, аса қауіпті инфекциялар, биологиялық қару, вирус, патогенді бактерия, риккетсия, токсиндер, тактика, тергеу әрекеттері.

Тапалова Р.Б. ${ }^{1}$, Темірболат Н.С. ${ }^{2}$, Ааубасова С. ${ }^{3}$, Арвинд Т.Т. ${ }^{4}$

${ }^{1}$ К.ю.н., Аоцент, e-mail: tapalova r@mail.ru

${ }^{2}$ К.ю.н., и.о. Аоцента, e-mail: nuraishamail@gmail.com

${ }^{3}$ старший преподаватель, e-mail: daubassova2017@gmail.com

Казахский национальный университет имени аль-Фараби, Казахстан, г. Алматы

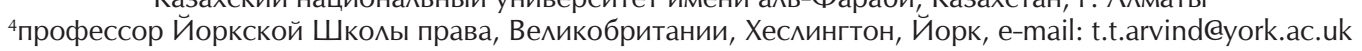

Патогенные микроорганизмы

как элемент криминалистической характеристики биотерроризма

Статья посвящена криминалистическому анализу обстоятельств поражения материальной среды патогенными микроорганизмами при совершении акта терроризма. Тема актуальна тем, что она до настоящего времени не изучена в криминалистической китературе, не рассматрива^ись такие понятия, как «особо опасные инфекции», «биологические агенты», «бактериологическое оружие», «биологическое оружие», «патогенность», «контагиозные свойства» и т.А. В криминалистике не систематизированы свойства разработанных к настоящему времени биологических агентов биологического оружия, механизм и характер следообразования в той материальной обстановке, гАе может быть совершен террористический акт с применением указанных средств. Не рассматривались вопросы технико-криминалистического обеспечения проведения поисковых слеАственных действий, например, при осмотре места происшествия, если совершен акт терроризма, нет рекомендаций по тактическим особенностям расследования Аанной категории преступлений, не известны, в какой процессуальной форме Аолжны привлекаться специалисты, какие обстоятельства и с помощью каких специалистов должны быть установлены для доказывания виновности террориста (-ов), а также не разработаны и другие вопросы, составляющие методику расследования терроризма.

Цель исследования, исходя из свойств патогенных микроорганизмов природного происхожАения и биологических агентов Аля созАания биологического оружия, существующей их классификации по степени патогенности, по способу проникновения и т.А., - выАелить основные свойства эти микроорганизмов в криминалистическом аспекте, систематизировать их Аля определения тактики проведения следствия на начальном этапе расследования.

Методологической основой послужили научные труды микробиологов, вирусологов, биологов, эпидеомиологов, военных эпидеомиологов, посвященные биологическим агентам, биологическому оружию, методам индикации бактериалогического материала, а также труды криминалистов, посвященные теории и практике расследования отАельных видов преступлений.

Кмючевые слова: акт терроризма, патогенные микроорганизмы, биологические агенты, особо опасные инфекции, биологическое оружие, вирус, патогенная бактерия, риккетсия, токсины, тактика, следственные действия. 


\section{Introduction}

The Criminal Code of the Republic of Kazakhstan, taking into account international experience in the methods of committing acts of terrorism, international experience in combating terrorism, has significantly expanded the acts of possible forms of acts of terrorism. In Chapter 10 of the Criminal Code of the Republic of Kazakhstan "Criminal Offenses Against Public Security and Public Order", 15 compositions are classified as terrorist offenses (http://adilet.zan.kz/rus/ docs/ $\mathrm{K} 1400000226 \# \mathrm{z} 927$ ). The act of terrorism (the most serious act) in accordance with Article 255 of the Criminal Code of the Republic of Kazakhstan is considered as an offense transformed into a multi-object crime, where the main object remains public safety, and additional objects are life, health, property and other law-enforcement benefits. The legislator, when describing the signs of the objective side of an act of terrorism, uses the concepts of methods - " ... carrying out an explosion, arson ... ... or spreading epidemics or epizootics, as well as other actions, capable of causing massive death of people. "indicated as one of the dangerous ways for terrorists to use causative agents of infectious diseases (pathogenic microorganisms).

The pathogenic microorganisms existing in the nature became the objects of research for the military - industrial sphere in a previous century (Konovalov, 2014; Alibek, 2003; www.portal-slovo.ru). The results of those researches led to the creation of the biological weapon, the main component of which were the biological agents (or cultivated pathogenic microorganisms or the causative agents of especially dangerous infections cultivated in laboratories). The proportion of the meanings is following: biological weapon and biological agents are like the whole and the part. The meaning of a biological weapon is wide: it unites the set of carrier and organisms of wildlife, which, by negatively influencing on other objects of wildlife (human, fauna, flora, including house animals and crops), causes significant harm, can lead to lethal outcome, at the same time has the ability to extend by itself, resulting in epidemic, pandemic, epizooty, epiphytotic. The carriers can be different: it can be warheads of cruise missiles in a military sphere and container, even a plastic bag, in terrorist's arm.

Now all the types of biological weapons are illegal: several conventions were adopted to forbid the development, storage and usage of biological weapons. For example, The Convention on the Prohibition of the Development, Production and
Stockpiling of Bacteriological (Biological) and Toxin Weapons and on their Destruction, which was adopted on 16 December 1971 (https://www. un.org/ru/documents/decl_conv/conventions/ bacweap.shtml). However, despite the convention, there is an information that biological weapon is continuing to be developed. The military experts think that biological weapon in some aspects is more dangerous than a nuclear one. It's properties and features seem like it can possibly lead to the elimination of humanity on the planet, as it was told by Russian scientific V.Y. Evstigneev at lection, which took place in Moscow Institute of Physics and Technology on 25 March and 8 April 2003 (Evstigneev, 2003).

The operation of the biological weapon does not differ by it's ingenuity. Virus or pathogenic bacterial does not sort where the ally or enemy is, having got on freedom, they destroy all the creatures on their path. After the usage of the pathogenic virus or bacillus of anthrax, nobody can guarantee that infection will not desolate even the attackers. The science is not capable of development of guaranteed protection from microorganisms yet. Furthermore, even if antidote is developed earlier, it can be ineffective, because viruses and bacteria always mutate (Alibek, 2003). As scientists think, the biological weapon was not used in military motives in a modern history due to this fact (Konovalov, 2014; Alibek, 2003: 228$231,233)$. It is probable that this tendency will be kept in the future.

However this point of view is not suitable to the situation with terrorists. Due to the fact that there are suicide executors, there is no guarantee that they can be stopped by the consequences of using the biological weapon. The range of organizations and individuals, which are able to use the biological agents as an instrument of terror, which differ by group structure, financial source, ideology, motivation and practicing methods, can be very various (Schmid, 1983: 119-158).

It consists of huge, well-paid organizations, oppositional rebel groups, religious and cult sects, which propagandize the ideology of "Apocalypse", various types of nationalist groups, separated political movements and groups, also single terrorists (Taylor, 1991: 135).

As stressed by foreign researchers in the last century (Crozier, 1974: 130; Jenkins, 1984: 23; Laqueur, 1987: 97; Laquer, 1999; Schmid, 1983: 119-158; Taylor, 1991: 135; Grosscup, 1987: 78) and now (Laquer, 2001: 80) certain political, nationalist, religious organizations of radical- 
extremist orientation consider it permissible to use any violent methods to achieve their goals.

The dangerous tendency in a progress of terrorism during the conditions of globalization is the fact that criminal terrorist organizations choose much more sophisticated ways of terrorist attacks, use advances of science and technology, so that now the possibility of using the mass destructive weapon by them (chemical, biological, nuclear) comes real (Zhiganova).

The danger of bioterrorism is determined by a number of prerequisites, as Alibek K. (Alibek, 2003), Beljakov V.D. (Beljakov, 1988), etc. indicate, they include the following factors:

1.High effectiveness of using various types of biological weapons by terrorists, it can cause an epidemic in a short term, which leads to the death of an enormous quantity of people, animals and crops. Many biological weapons are capable of epidemic spread.

2. Microorganisms can get into every facility, there is no guaranteed protection from them by engineering structures.

3. The big variety of biological agents, which can be used for destruction of enemies: there is a significant number of possible sources for biological weapons, including natural centers, grounds to examine the biological weapon. According to approximate data, there are collections of various bacterial strains in 67 countries, which belong to several organizations, medical centers in several states have causatives of anthrax and plague. The quantity of sources of lethal bacteria and inadequate security of storage locations can turn medical and biological centers to voluntary and involuntary sources of biological weapon supply for terrorists.

4. The production of certain types of biological weapon does not demand any special equipment and it is not very difficult, according to producers (Evstigneev, 2003), developing this weapon will not be so difficult even for countries with low level of technical progress.

5. The biological weapon is easily transported and hardly found out by any type of inspection: in fact, each infection demands special methods of treatment and prevention, so it makes the possibility of preparing for reflection of any potential attack very difficult.

6.The difficulty of timely detection of use of biological weapon by enemy and the presence of incubation interval of contamination make the fact of use less noticeable; due to uncertainty of who and where will try to do bioterrorism attempt and what biological agents will be used as an instrument of terror, the threat and attempts to use biological weapons will always remain.

7. The ability of biological weapon to strike people, animals and agricultural plants. However this ability is very selective: one type of pathogens calls the human diseases, whereas another harms only animals.

8. A biological weapon makes a strong psychological impact on population, the panic and fear will appear immediately.

However this type of mass destruction weapon has a significant disadvantage, which limits it's use - it is extremely nonselective, but terrorist may ignore this factor (Evstigneev, 2003).

The investigation of bioterrorist attack differs from investigation of another crimes:

- By high mental tension of investigator's work, due to emergency regime.

- By necessity of regular operational response.

- By regular cooperation with forces, which must perform protective measures, apply measures of immune and emergency preventions from diseases among people, animals, plants, that means disinfecting the territory, damaged by attack.

The complex of necessary measures during investigation depends on natural and military properties of used pathogenic microorganisms. In 1998, the Ministry of health care of the USSR approved the list of pathogenic agents so that security and protective measures were taken against them. Then and later the list of especially dangerous infections, which have natural sources in Kazakhstan, was approved by order №62 of Minister of health care (https://online.zakon.kz/Document/?doc $\mathrm{id}=30086861 \#$ pos $=0 ; 0)$. The list of infections is following: plague, tularemia, anthrax, brucellosis, Congo-Crimean hemorrhagic fever, hemorrhagic fever with nephrotic syndrome, smallpox, botulism, tick-borne encephalitis, cholera. The causatives of infections, which are very dangerous for people according to list, have different levels of pathogenicity. Despite the medical advances, some infections depending on organ they harm and degree of injury can lead to a lethal outcome.

Sometimes in remote regions of Kazakhstan outbreaks of anthrax, or brucellosis, or CongoCrimean hemorrhagic fever, or cholera, tick-borne encephalitis plague in certain seasons. Each case of disease is determined by relevant services by the list of especially dangerous infections. According to data of the Ministry of health care, so far all infections were caused by nature. In the presence of bases, acts of criminal character were considered as a break of sanitary regulation or hygienic standards, 
a violation of veterinary rules a criminal negligence, inaction on service, concealment of information about circumstances that create a danger for life and health of people.

Due to the development of tourism and frequent cases of diseases among tourists by brought in infections, Kazakhstan scientists as virologists, infectiologists, microbiologists studied and gave description of clinic symptoms in a monograph, which was devoted to tropic infections - malaria, sleeping sickness (African trypanosomiasis), Chagas disease (American trypanosomiasis), leishmaniosis, leprosy, yellow fever, Marburg hemorrhagic fever, Ebola hemorrhagic fever, schistosomiasis, filariasis, onchocerciasis (Amireev, 2014).

The list of dangerous microorganisms does not end with this; due to region on Earth, there are another pathogenic microorganisms in wildlife such as Bolivian hemorrhagic fever, Venezuelan equine encephalomyelitis and so on (Onishenko, 2003). What is the difference between natural pathogenic microorganisms and pathogenic microorganisms, which are biological weapon? A difference is very essential. Scientists, who developed biological weapon, had the task to strengthen the pathogenicity of microorganisms, in contrast to natural ones, to make them stable to impact of climatic factors, action of antibiotics, to endow with property for production in industrial scales, to make it possible to keep them in a long-term, to adopt for transportation.

According to military epidemiology, biological weapons should have the following criteria:

have a higher pathogenicity in comparison with the natural analogue; its impact must have combat effectiveness; the possibility of cultivating the pathogen; resistance of the pathogen; simplified ways of transmission, infection; to be epidemic. Even for the selection of biological weapons attention is paid to species immunization; therapy; detection of pathogens; the reverse action (Evstigneev, 2003).

It is very important in a biological warfare that dangerous agents had high pathogenicity, the number of microbes necessary to damage planned objects must be extremely minimum.

The fighting efficiency means that biological weapon must have the ability to strike and disable the object of attack. Also it consists of the quantity of death (number of death per each hundred of population); approximate duration of a sharp stage of a disease (period, when person is exhausted at all); character and duration of recovery period and duration of incubation interval.

The criterion of causative's existence assumes that there must be a method to get this agent in a necessary number. If we need to get a large amount of causatives, we should create appropriate cultures. It relates to a majority of infectious agents, because lots of bacteria can be grown up in simple environments, some of them need special nutrition and even vitamins. Fungi can grow up in even simpler environment. Rickettsia and viruses can not grow up this way, they breed only in cells of suitable person. It was found that lots of rickettsia and viruses breed well, when they are inoculated, for example, into chicken eggs and under appropriate conditions.

The criterion of stability means ability to cope with influence of environment, which makes a destructive impact on microorganisms (drying, effect of ultraviolet, high temperature and high concentration of disinfectants), also stability is a property to keep virulence in field conditions. The virulence of dangerous bacteria can weaken or disappear in adverse or even favorable conditions. Stability of the least stable bacterium can be increased by laboratory processing. Unstable, but very convenient agent can be stabilized. But this quality may change the way of use of an agent. More stable causatives as spores of anthrax can be used to strike open areas, because in conditions like this they can live very long, according to researchers, they live 10 years. The least stable ones, for example, bacilli of tularemia and cocci of meningitis can transfer by positive gearing from source to object, for example, via droplet nuclei.

The criterion of transmission and epidemic (the ability to transfer from one infected to another) concerns the question of tactical use of agents in biological war. The criterion of epidemic can be missed during selection, but transmission ways of infection are necessary to be considered. Yellow fever and sapropyra are the examples of diseases that transfer via insects in natural conditions, however, undoubtedly, they can extend also by air. Despite the fact that airborne transmission is the most widespread way of mass infection of people in a bacteriological war, we should not ignore other ways of infection.

The criterion of immunization and therapy is defined by the fact that average efficiency of any agent depends on presence of effective medicine to protect the population by vaccination or preventive measures or treatment by strong medical antibiotics.

The criterion of detection means the difficulty in identification of an agent in region attacked by agent during bacteriological war.

The criterion of retroaction is the ability of agent to strike anyone, who used biological weapon. This ability depends on 2 qualities of biological 
agents: pathogenicity and epidemic features. The first quality determines direct danger for those, who work with pathogens and use them; the second one has a big importance due to possibility of epidemic disease to spread to even users.

The listed combat properties used in biological weapons of pathogenic microorganisms, as evidenced by scientists, depend on the technology of laboratory processing. This means that the causative agents of the same type will have different combat properties depending on the technology.

Attention should be paid to this data. In terms of evidence, subject to the use of biological agents by terrorists, it is possible to identify the source of the biological agent.

Thus, the concept of "pathogens of natural origin" and the concept of "biological agent" are not identical. Biological agent is considered as a component of biological weapons. Terrorists can use both natural pathogens and cultured strains developed under laboratory conditions related to components of biological weapons to carry out their criminal intentions.

As noted in scientific sources, in all published lists, the quantitative and qualitative composition of biological agents considered as weapons for military purposes is constantly changing, microbiologists, bacteriologists in many countries continue to research, but the list of "classical" is sufficiently formed and consists of the following agents:

1. Pathogens of viral origin: natural smallpox, hemorrhagic fever Marburga, Ebola, Lassa, Bolivian hemorrhagic fever, Venezuelan horse encephalomyelitis, Eastern horse encephalomyelitis, yellow fever, Japanese encephalitis, Dengue fever, Rift Valley fever, hemorrhagic fever with kidney syndrome, Congo - Crimean hemorrhagic fever.

2. Causative agents of rickettsia nature: epidemic typhus, spotty fever of the rocky mountains, $Q$ fever.

3. Pathogens of a bacterial nature: plague, anthrax, tularemia, glanders, melioidosis, brucellosis, legionellosis.

4. Toxins of plant and animal origin: botulinum toxins, tetanus, anthrax, shigelle, staphylococcal and enterotoxins, ricin, neurotoxins, etc. (Onishhenko, 2003).

This interest to toxins is attracted by a range of advantages over causative agents of infectious diseases, as specialists claim. They are more stable at storage and use, they can be easily received in a large amount in scientific research laboratories, it is possible to use them secretly in sabotage and terrorist attacks, and the most important thing is that there is no incubation interval of disease, according to scientists, which brings toxins to chemical agents closer by tactical characteristics.

Therefore, according to the data of military epidemiologists, the list of agents added to a group of possible biological tools by specialists, which are in danger of use by terrorists, is widened by causative agents of virus nature and biological toxins now. It is not excluded that new agents developed by genetic engineering will be added to this list. However, scientists highlight that arsenal of antidotes which provide population with effective protection from biological agents is not full enough. This fact creates difficulties in the matter of specific and emergency prevention of a range of dangerous infectious diseases and defeats by toxins.

The tactics of initial investigative actions depend on what pathogenic microorganisms are used by terrorists.

There are several types of agents divided by objects of criminal encroachment:

1) biological agents that encroach lives and health of population and cause epidemic and pandemic (pathogens dangerous for people, viruses, rickettsia, bacteria, toxins, also every genetically changed microorganism and genetic element).

2) biological agents that harm crops and cause epiphytotic (pathogens dangerous for plants such as viruses bacteria, microscopic fungi and genetically changed microorganisms).

3) biological agents that encroach animals and cause epizooty (pathogens dangerous for animals, viruses (for example, causatives of foot-and-mouth disease, smallpox of sheep), bacteria and genetically changed microorganisms).

This classification into groups defines for the practice what specialists must be engaged to help investigation in a process of inspection of the scene, survey of corpses of animals, appointment of examination.

The next classification of pathogenic microorganisms important for investigation is the degree of expressiveness of pathogenicity (which is relevant for both natural and cultivated causatives):

1) the first row - virus of natural smallpox, the causatives of plague, anthrax, botulism (toxins), Marburg hemorrhagic fever, tularemia, glandes, melioidosis, flu, sapropyra, Venezuelan encephalomyelitis of horses;

2) the second row - the causatives of brucellosis, Japanese encephalomyelitis, yellow fellow, cholera, tetanic, toxins of diphtheria.

3 ) the third row - therabies virus, HIV, virus of parenteral hepatitis, the causatives of syphilis, gonorrhea, infections of staphylococcus. 
The next classification is based on abilities of pathogenic microbes to get into a human's organism in natural conditions:

1) by air via respiratory organs (airborne, aero genic);

2) by food and water via digestive tract (alimentary way);

3) via uninjured skin as a result of stings of infected blood-sucking arthropods (transmission);

4) via mucous membranes of mouth, nose, eyes, also via damaged skin drape (contact way);

The significance of two classifications determines the system of preventive measures, equipment of operational investigation group, tactics of carrying out inspection, questioning, search.

Then we should pay attention on carriers of pathogenic microorganisms. Terrorists must find ways to solve a problem of transportation to a place of attack and it's expansion. Militaries transported a biological weapon by air blast bombs and aerosol generators, artillery shells and mines, short and long-range missiles, which were loaded with containers full of necessary microorganisms, also by any other unmanned way of attack with containers filled with microorganisms. It is clear that these methods of transportation are not possible for the act of terrorism.

The most probable way is the presence of terrorists at a place of attack, as it was in Tokyo subway, and use of containers, various capacities and special tools (Zhiganova). In containers there may be fleas, mosquitoes, flies, louses, pincers, mice, rats, bees artificially infected by bacteria and viruses (entomological weapon) and biomaterial, which consists of dried up spores of anthrax. Capacities may be filled with biomaterial containing pathogenic microorganisms to strike water, air of enclosed space, food products.

Terrorist may choose one of the following ways of extending pathogenic microorganisms:

1) aerosol way - spraying biological mixture to damage ground layer of air by aerosol particles;

2) transmission - dispersion of bloodsucking carriers artificially infected by biological technologies in a target area.

3 ) infection of water and air in the closed spaces by biological agents.

All specialists agree that aerosol way is the main method of use. It allows infect ground masses of air, area and objects in this area in large spaces by pathogenic microorganisms. At the same time infection by biological aerosol causes manpower too, not only situated in open area, also situated in unpackaged facilities. The infection of air at places crowded by people is possible by using small-sized tools (portative aerosol generators, spraying cases) at particular time. Also it is possible to infect water in urban water systems.

Transmission means deliberate dispersion of blood-sucking carriers artificially infected by biological substances in entomological tools (containers of special construction) in a planned region. Transmission way is based on a property of a big majority of existing blood-sucking arthropods to take easily, keep for a long time and then transfer causatives of diseases dangerous for people and animals via biting. For example, separate species of mosquitoes can transmit yellow fever, Denge fever, Venezuelan encephalomyelitis of horses; fleas - plague; louses - sapropyra; ants - pappataci fever. The use of artificially infected carriers is the most possible in a warm season and in conditions similar to their natural conditions. Amongst all ways of distribution of pathogenic microorganisms the surest bet is the use of fleas, mosquitoes, louses, pincers artificially infected by bacteria and viruses. In fact there are three types of entomologic weapon:

1) the first type means infection of insects by pathogens and their distribution in a target area; these insects act as a factor infecting people and animals who can be bitten;

2) the second type of entomologic weapon uses insects to harm crops; in this case, it is not necessary to infect insects, however they must pose a threat for crops;

At various times agricultural pests cultivation programs existed to cause a loss on enemy's economy. That is why we should consider a form of bioterrorism like agroterrorism (Zhiganova).

Agroterrorism is the use of chemical or biological weapon against agricultural enterprise or food industry of enemy. The danger of agroterrorism consists not only of loss that terrorism can cause at agriculture and trade. Ken Foster, the professor of agricultural economics at Purdue University, claims that a damage from actions of terrorists in this sphere may be significantly heavier in comparison with simple epizooties and epiphytoties, because terrorists can find the weakest spot in a control system and strike several places at same time in a convenient moment (Zhiganova). The damage that agroterrorism can cause directly depends on a time which is necessary for detection of problem; the longer epizooty and epiphytotic will develop, the more difficult it will be to stop it's distribution and the more extensive will be the damage. Sometimes a foot-and-mouth disease epidemichappensin Kazakhstan and there were cases of diseases of 
cattle by anthrax, which led to a break of contracts on supply of meat with China, however, no one thinks about the reason of animal disease and loss that our country has.

\section{Research result.}

Pathogenic microorganisms of natural origin are not identical to the concept of "biological agent", which is a component of biological weapons. The biological agent, as the causative agent of a particularly dangerous infection, must meet the criteria of military weapons and has a greater degree of pathogenicity and other combat properties. However, terrorists can use any pathogenic microorganisms to carry out their criminal plans. When using cultured microorganisms for proof, it is possible with the help of specialists to establish the source of the biological agent.

The classification of pathogenic microorganisms according to the degree of pathogenicity, the method of penetration into the human body, the method of influence on people, animals, plants, the method of their use in carrying out an act of terrorism are important for determining specific tactics when conducting investigative actions.

\section{References}

Amireev S.A., Sejdulaeva L.B. i dr. (2014) Tropicheskie infekcii. - Almaty. - 655 s.

Alibek K., Hendel'man S. (2003) Ostorozhno! Biologicheskoe oruzhie! - Izdatel'stvo «Gorodec-izdat». - 240 s.

Beljakov V.D, Zhuk E.G. (1988) Uchebnoe posobie po voennoj gigiene i jepidemiologii. - M. - 320 s.

Crozier, B.A. Theory of conflict. - London: Hamilton, 1974. - P.130.

Evstigneev V.I. Biologicheskoe oruzhie i problemy obespechenija biologicheskoj bezopasnosti. Tezisy lekcii V slushatelej kursa..I. Evstigneeva, prochitannoj 25 marta i 8 aprelja 2003g. v Moskovskom fiziko-tehnicheskom institute dlja

Grosscup, B. The Explosion of Terrorism. - Far Hills, NJ: New Horizons, 1987. - P.78.

Jenkins, B. The Who, What, What, Where, How and Why of Terrorism // Paper presented at the Detroit Police Department Conference on «Urban Terrorism: Planning or Chaos?» - November. - 1984. - P.23.

Konovalov P.P., Arsent'ev O.V., Bujanov A.L., Nizovceva S.A., Masljakov V.V. Primenenie juiologicheskogo oruzhija Istorija i sovremennost'. // Sovremennye problemy nauki i obrazovanija. - 2014. - № 6.; URL: https://www.science-education.ru/ru/article/ view?id=16621 (data obrashhenija: 08.06.2017).

Konvencija o zapreshhenii razrabotki, proizvodstva i nakoplenija zapasov bakteriologicheskogo (biologicheskogo) i toksinnogo oruzhija i ob ih unichtozhenii.16 dekabrja 1971g.

Schmid, A.P. Political Terrorism: A research guide to concepts, theories, data bases, and literature. - New Brunswick, NJ: Transaction Books, 1983. - R.119-158.

Respublika Kazahstan. Ugolovnyj kodeks ot ot 3 ijulja 2014 goda № 226-V (s izmenenijami i dopolnenijami po sostojaniju na 02.08.2017 g.) URL: http://adilet.zan.kz/rus/ docs/K1400000226\#z927.

Taylor, M. The Fanatics: A Behavioral Approach to Political Violence. - McLean, VA: Brassey’s, 1991. - R.135.

Laquer W. The Age of Terrorism. - Boston: Little Brown, 1987. - P.97.

Laquer W. The new terrorism /Fanatism and the anus of mass destruction. - New York: Oxford, 1999. - 640 p.

Laquer W. Left, Right, and Beyond: The Changing Face of Terrorism. How did this Happen? // Terrorism and the New War. NY: Public Affairs, 2001. - P.80.

Prikaz Ministra zdravoohranenija Respubliki Kazahstan ot 15 dekabrja 2006 goda № 623

Protivodejstvie biologicheskomu terrorizmu. Prakticheskoe rukovodstvo po protivojepidemicheskomu obespecheniju / Pod red. G.G. Onishhenko - M., 2003. - 304 s.

Zhiganova L.P. Bioterrorizm i agroterrorizm - real'naja ugroza bezopasnosti obshhestva. htth: //www.portalslovo.ru/impressionism/36426.php

www.portal-slovo.ru > Estestvoznanie > Biologija > Obshhaja biologija //Sb.Novyj terror: pered licom ugrozy ispol'zovanija biologicheskogo i himicheskogo oruzhija. 